\title{
LA LITERATURA HISPANOAMERICANA Y EL EXILIO
}

\author{
POR \\ Claude Cymerman \\ Université de Rouen, France
}

Dijo una vez Julio Cortázar: "Algún día en las historias de la literatura latinoamericana habrá un capítulo que será el de la literatura del exilio." De hecho, el exilio es tan antiguo en Hispanoamérica como la misma historia del continente desde la Independencia y buena parte de la literatura hispanoamericana ha sido escrita en el exilio. Eduardo Galeano señala acertadamente que "las novelas más latinoamericanas de estos últimos tiempos fucron escritas fuera de nuestras fronteras."' Y Juan José Saer insiste, por su parte, sobre el hecho de que "toda la literatura argentina del siglo XIX fue escrita por exiliados."3 El primero, Ricardo Rojas, había abonado el terreno al escribir, en 1919, el capítulo "Los proscriptos" de su Historia de la literatura argentina. Hoy, el espacio y el momento son otros. No se trata tan sólo del exilio argentino - jmuy concurrido por otra parte!- ni del siglo XIX. En esta época finisecular que es la nuestra se trata — isin la pretensión de emular a Rojas! - de acercarnos al tema de la literatura del exilio de los decenios 70 y 80 de nuestra vigésima centuria. Trágico y cruento período en que se dieron las, probablemente, peores dictaduras militares que ensangrentaron la historia de las naciones del Cono Sur - Argentina, Chile, Paraguay, Uruguay - sin que los quebrantos de la política hayan dejado totalmente a salvo otras repúblicas como Colombia, Cuba, Nicaragua, Perú, El Salvador o Venezuela, por no tener que enumerar a la casi totalidad de los países hispanoamericanos. Forzoso es constatar, por otra parte, que la revolución castrista, después de derrotar a la dictadura de Battista, ha incurrido en un totalitarismo que ha llevado al exilio a numerosos cubanos y a muchos intelectuales de la isla.

A esta altura, conviene hacer, por lo menos, dos aclaraciones previas. La primera es que, si bien motivos políticos y económicos son interdependientes y se confunden a menudo, se ha hecho tradicional entre nosotros llamar inmigración las migraciones impuestas sobre todo por la coyuntura económica y reservar el nombre de exilio a las migraciones motivadas por razones fundamentalmente políticas. Por otro lado, se suele emplear el nombre de exilio cultural — designación discutible pero cómoda y adoptada por casi todos los estudiosos en la materia - para referirse al exilio impuesto, en particular, por

${ }^{1}$ Cambio 16, 489 (13-4-1981) 101.

2 "L'exil, entre la nostalgie et la création", en Amérique Latine: Luttes et mutations (Paris: F. Maspéro, 1981) 115 .

3 "Exil et littérature", en Les Temps Modernes, 420-421 (juillet-août 1981) 224-225. 
la situación en que se encuentra la producción del libro y la acogida por el público lector. La segunda aclaración es la siguiente. Literatura del exilio conlleva un doble sentido: sensu stricto, es la literatura de los autores - en su inmensa mayoría exiliados - que tratan en sus obras el tema del exilio; sensu lato, es toda la literatura - hable o no hable del exilioescrita por escritores hispanoamericanos desterrados. Otra terminología consecuente llegaría a distinguir la literatura del exilio, o sea, la que habla del exilio, y la literatura en el exilio, i.e. la que se escribe en el exilio. Nuestro proyecto, en este artículo, es abordar el tema a nivel general, o sea, incluyendo a las principales obras que se escribieron en el exilio entre 1970 y 1990 aproximadamente, hablen o no del exilio. Por lo tanto adoptaremos el título más englobante de La literatura hispanoamericana yel exilio (1970-1980), dividiendo nuestro estudio en las dos partes fundamentalmente aludidas hace un instante. Pero antes nos conviene decir algo de las relaciones que median entre la literatura y el exilio.

\section{LA LITERATURA Y EL EXILIO}

La literatura argentina es indudablemente la que pagó el mayor precio a la dictadura y la que cuenta el mayor número de exiliados. Entre los escritores de aquel país, llegamos a contar a veinticinco representantes afamados que no dejaron de escribir fuera de su país de origen (algunos, incluso, encontraron en el exilio una vocación de escritor). Entre los exiliados en Francia, que, salvando el caso del autor de Rayuela, nacieron casi todos en los años 300 a principios de los 40 , se pueden citar nada menos que a Hector Bianciotti, Arnaldo Calveyra, Julio Cortázar, Edgardo Cozarinsky, Alicia Dujovne Ortiz, Luisa Futoransky, Juan Gelman (que residió también en Italia), Mario Goloboff, Gregorio Manzur, Rodolfo Rabanal (que se fue a vivir después a Estados Unidos), Juan José Saer, Osvaldo Soriano, Federico Undiano, Saúl Yurkiévich. A España emigraron Vicente Battista, Antonio Di Benedetto, Juan Carlos Martini, Daniel Moyano, Héctor Tizón, David Viñas, y a México, Pedro Orgambide, Tomás Eloy Martínez y Mempo Giardinelli. Manuel Puig encontró refugio en México, primero, en Brasil, después. No sabemos donde permaneció Humberto Costantini. Pero los argentinos, si fueron los más numerosos, no fueron los únicos obligados a abandonar a su país por culpa de la dictadura. Se exiliaron los uruguayos Mario Benedetti, Carlos Rama, Eduardo Galeano, Juan Carlos Onetti, Cristina Peri Rossi (en España), Fernando Ainsa y Ángel Rama (en Francia), Emir Rodríguez Monegal (en Estados Unidos); los paraguayos Rubén Bareiro Saguier y Augusto RoaBastos (en Francia), Gabriel Casaccia (a Argentina, antes de la dictadura). Los chilenos se desparramaron en varios países : José Donoso, exiliado cultural más que político, en Estados Unidos y en España, Jorge Edwards, en Francia, Antonio Skármeta y Luis Sepúlveda, en Alemania, Isabel Allende, en Venezuela y en Estados Unidos. Los peruanos Alfredo Bryce Echenique y Manuel Scorza emigraron a Francia (aquél se fue después a España), Julio Ramón Ribeiro (entre exiliado cultural y funcionario en el extranjero) reside en Francia, Mario Vargas Llosa vivió su exilio cultural en España, Francia y Gran Bretaña. Gabriel García Márquez tiene la particularidad de haber dejado Colombia ya a los dieciséis años y de haber pasado largas o cortas temporadas en el mayor número de países (Italia, Francia, España, México, Estados Unidos, Cuba). Flor Romero de Nohra, también colombiana, reside en Francia. En cuanto a los cubanos, Reynaldo Arenas, Heberto Padilla, Armando Valladares, Jorge Valls, el 
tiempo que no pasaron en la cárcel, lo pasaron generalmente en Estados Unidos; Guillermo Cabrera Infante se fue a vivir a Gran Bretaña, y Severo Sarduy a Francia. Dejamos de lado a los que se pasaron largos años en el extranjero, no como exiliados sino con funciones diplomáticas, cual César Fernández Moreno o Abel Posse que se sucedieron en la agregaduría cultural de la República Argentina en París. Nos merecen por lo menos una mención dos prestigiosos escritores argentinos, Haroldo Conti, que no pudo exiliarse porque fue asesinado por los militares y Ernesto Sábato, que, si bien no emigró, vivió durante la dictadura un auténtico exilio interior. De hecho, son muchos los escritores (Piglia, Rivera) que se quedaron en la Argentina durante el tristemente famoso "Proceso de Reorganización Nacional" y tuvieron que vivir un auténtico exilio interior, escribiendo "para el cajón", o usando, para sortear la censura, una escritura alusiva o elusiva, críptica o elíptica, eufemística o alegórica. No deberían, además, discutirse las bondades o méritos respectivos de los que "se fueron" y de los que "se quedaron". Ni puede decirse -como parece que dijo Manuel Mujica Láinez - "los grandes somos los que nos quedamos", ${ }^{4}$ ni puede pensarse que lo mejor de la literatura argentina o hispanoamericana se escribió en el extranjero. Tanto en el interior, cerca de sus raíces pero bajo el yugo de la dictadura, como en el exterior, en la libertad pero lejos de sus fuentes, siguió explayándose la literatura.

En total fueron unos cincuenta los escritores hispanoamericanos prestigiosos - la mitad de ellos argentinos- que tuvieron que dejar a su país para escapar de la dictadura, la cárcel, la tortura, las "desapariciones", la muerte. ${ }^{5}$ El balance es cruel y bochornoso. El exilio dejó terribles secuelas para todos y empobreció culturalmente los países que expulsaron a sus intelectuales. Sin embargo no todo fue negativo. Roa Bastos sostiene con razón que la literatura paraguaya no existiría sin el exilio, ya que sólo en el exilio se pudo desarrollar. Considera incluso que el exilio puede resultar positivo para la creación en la medida en que el alejamiento provoca un "distanciamiento" con respecto al país de origen y que este distanciamiento, si bien corta al escritor de sus fuentes locales de información, puede significar también una mayor objetividad:

El exilio tiene sin embargo la ventaja que da al escritor, al artista, al intelectual, una cierta distancia, una cierta perspectiva con respecto a su realidad. Le permite entrar en ese trabajo más profundo y sutil de la reflexión sobre lo que constituye la realidad de un país. ${ }^{6}$

Además, el exilio no aleja la creación de sus fuentes originales. Cortázar reclama contra los que niegan la argentinidad de su obra:

Arguedas, con su gran ingenuidad y su gran corazón, insistía en que los peruanos tenían que escribir en Perú y que los argentinos tenían que escribir en Argentina. Yo pienso que

\footnotetext{
${ }^{4}$ Noé Jitrik, "La literatura del exilio en México" en Karl Kohut y Andrea Pagni, Literatura argentina hoy: De la dictadura a la democracia (Frankfurt: Vervuert, 1989) 161.

${ }^{5}$ No hacemos entrar en la cuenta a los "exiliados culturales" que no dejaron a su país para huir de la dictadura sino para encontrar mejores condiciones de trabajo a nivel de la creación y de la edición. Lo que no quita que razones políticas pueden haber contribuido a crear las condiciones del exilio cultural (del mismo modo que la inmigración, determinada por motivos económicos, puede haber sido predeterminada por causas políticas).

${ }^{6}$ Karl Kohut, Escribir en Paris (Barcelona: Hogar del Libro, 1983) 238-239.
} 
eso depende del temperamento de cada uno. Creo haber escrito una obra profundamente latinoamericana y especfficamente muy argentina, y la he escrito en Paris, capital de Francia. [...] No necesito estar en este momento mismo en Buenos Aires para sentir, con los sentidos interiores, el olor de las calles de Buenos Aires, el sonido que tiene la ciudad. [...] Es decir que me he traído Buenos Aires a París, de la misma manera que cuando viajaba a la Argentina y estaba en mi casa de Buenos Aires, de golpe pensaba en París y, bueno, París estaba ahí conmigo, me envolvía. ${ }^{7}$

En lo que atañe a la recepción de la obra, ahí también el exilio puede ser beneficioso en la medida en que el escritor encuentra un nuevo público. "Nadie es profeta en su tierra." Este dicho, a menudo verdadero, lo es aun más en una América Latina que, sometida durante mucho tiempo a una política cultural eurocentrista, ignoró a menudo a sus escritores para reconocer tan sólo a los escritores extranjeros o a los escritores nacionales inspirados por la cultura extranjera. Y eso al punto que algunos debieron expatriarse para encontrar la consagración (Donoso, Vargas Llosa) o que otros, que permanecieron en su país, se encontraron encerrados en un verdadero gheto cultural (es el caso, por ejemplo, de toda la literatura argentina del interior, cuyos representantes - Di Benedetto, J. J. Hernández, Moyano, Tizón - sufrieron de cierto ostracismo hasta el punto de que sus propios compatriotas llegaron a considerarlos, no como escritores argentinos representativos, sino como escritores regionales ofolklóricos). De hecho, toda la literatura del boom ha sido concebida fuera del país de origen, lo que nos parece significativo del aporte positivo del exilio.

Agreguemos - no es lo menos paradójico del asunto-que el exilio del escritor puede resultar útil para el propio país. En efecto, condenado en casa al silencio y a un exilio interior esterilizante, puede, en cuanto ha pasado las fronteras, romper el corsé que lo aprisiona y, valiéndose de su notoriedad, denunciar la dictadura y hacer que progrese la causa de la libertad y de la democracia. Y este exilio puede resultar igualmente positivo para el país de acogida en lamedida en que los contactos entre escritores nacionales y exiliados contribuyen a enriquecer el conocimiento por los primeros del país de los segundos y, por vía de consecuencia, a permitir que éstos "se abran al mundo".

Conviene, sin embargo, interrogarse sobre la acogida que se reservó a los exiliados en el país donde encontraron refugio. Cuatro fueron, principalmente, los países que acogieron a los exiliados hispanoamericanos: España y Francia en Europa, México y Estados Unidos en América. Los testimonios no abundan sobre la acogida y las condiciones de trabajo en Francia y EE.UU. (lo cual tendería a demostrar que fueron relativamente buenas). En cambio, muchos escritores se han confiado acerca de su vida en España o México. En este último caso, los escritores coinciden generalmente en pensar que la acogida fue comparable con la que México dispensó a los españoles después de la victoria franquista en el 39: generosa y fructífera. ${ }^{8}$ En cambio, la recepción por los españoles, incluso por los intelectuales, de los hispanoamericanos exiliados en los años 70 y 80 es muy discutida y

\footnotetext{
${ }^{7}$ Karl Kohut 214-15.

8 "El exilio argentino en México tuvo una especie de florecimiento productivo, algo que me parece muy excepcional". "En México hay como una tradición de recepción del exilio casi institucionalizada que podríamos llamar la tradición cardenista.", escribe Noé Jitrik, 159 y 295, respectivamente.
} 
criticada. Daremos dos ejemplos significativos, el de un argentino, Juan Carlos Martini, y el de una uruguaya, Cristina Peri Rossi. El testimonio del primero es rotundo:

\begin{abstract}
Barcelona no era ya la amable cuna -ni siquiera la tolerante cama - de los autores latinoamericanos. [...] La hasta entonces progresiva capital de Cataluña iniciaba su decadencia posfranquista para sumirse en la miopía del nacionalismo y en la mezquindad de los pequeñoburgueses convertidos en banqueros y políticos. [Con el triunfo de la democracia] los síntomas chauvinistas y discriminatorios no se suavizaron. Por el contrario, en Cataluña, simbólicamente enfrentada desde hace siglos con el madrileño poder central, el desprecio por los latinoamericanos continuó profundizándose, y la denominación genérica y despectiva de 'sudacas' se popularizó.?
\end{abstract}

Martini trae a colación un artículo de Carlos Barral, titulado "La deuda inoportuna", según el cual los españoles no estaban en condiciones de retribuirles a los hispanoamericanos la generosidad demostrada en el 39 -ni estaban por lo tanto dispuestos a hacerlo. Más adelante alude a las dificultades experimentadas para quedarse en España o, a fortiori, para adquirir la nacionalidad española, y concluye su diatriba expresando explícitamente sus reservas acerca de "el suelo que con sospechosa lealtad filial se insiste en llamar "madre patria'."

Cristina Peri Rossi no es más indulgente. Centrando su comentario sobre la integración a nivel universitario, señala que "la universidad española siempre estuvo cerrada para los latinoamericanos", primero por culpa de una política franquista de puertas adentro y después por la toma de conciencia de las deficiencias engendradas por esta política:

La universidad española ha tenido un profundo complejo de inferioridad venido del franquismo y entonces no ha querido competencia para evitar que se noten las deficiencias. Incluso por acá ha pasado gente importantísima como Carlos Martínez Moreno, el escritor uruguayo, y no se le consideró jamás ni para una conferencia. Por acá pasó Roa Bastos cuando tenía el problema de que la dictadura paraguaya lo dejó sin nacionalidad y no pudo quedarse en Esparia porque ni siquiera le arreglaron los papeles. Se tuvo que ir a Francia a dar clases de literatura guaraní. ${ }^{10}$

Cristina Peri Rossi señala además que la política española de puertas cerradas alcanza igualmente al sector periodístico y perjudica especialmente a las mujeres. Y concluye amargamente:

Hay que pagar un derecho de piso muy duro en España, que pasa por la humillación de tener que aceptar que te corrijan palabras porque ellos creen que son los dueños del idioma, que te paguen menos que a un español porque no eres española.

No queremos insistir más en este aspecto ingrato -y patético- del exilio. De todas formas, pensamos que corresponde a una triste realidad que no se debe ocultar, aun cuando

9 "Exilio y ficcion: Una escritura en crisis", en Karl Kohut y Andrea Pagni, Literatura argentina hoy: De la dictadura a la democracia (Frankfurt: Vervuert, 1989) 141-142.

${ }^{10}$ Cynthia Vich Flórez, "Entrevista a Cristina Peri Rossi", en Scriptura, 8-9 (Universidad de Lérida, 1992) 229-230. 
no se pueden generalizar los casos expuestos. Y pasamos, acto seguido, a estudiar las diferentes modalidades de la literatura en el exilio.

\section{LA LITERATURA EN EL EXILIO}

\section{La novela histórica}

Muchos observadores (Fernando Ainsa, Claude Fell, pero también Fernando del Paso, Abel Posse, etc.) han señalado un interés renovado, a partir del $80 \mathrm{y}$ a nivel continental, por la novela histórica. Unos ven sobre todo en este interés el reflejo de un movimiento de repliegue y de búsqueda de la identidad, mientras otros descubren allí una necesidad de comprender el pasado y huir del presente. " La mayoría coincide en pensar que la nueva tendencia nace de la voluntad de denegar la "historia oficial" $y$, para algunos, de negar el valor objetivo y científico de la "Historia". El caso es que abundan las ficciones históricas, hasta el punto de que una recensión llevada a cabo por Ainsa abarca unas cuarenta novelas latinoamericanas escritas en los últimos veinte años ( $\sin$ que se pueda decir a ciencia cierta cuáles se concibieron en el exilio).

Al publicar en 1974 Yo, el Supremo, Augusto Roa Bastos (1917) dio una de la cuatro obras más importantes que versan sobre el tema del dictador (las otras tres son El señor Presidente de Asturias, El recurso del método de Carpentier y El otoño del patriarca de García Márquez). Yo, el Supremo, escrito en una lengua barroca que mezcla el lirismo de las descripciones con el humor lapidario del boceto, es, a la vez, una recreación libre de la dictadura de José Gaspar de Francia y una meditación sobre el poder y la condición humana. Vigilia del Almirante (1992), dedicado a la figura de Cristóbal Colón, mezcla —al ejemplo de El arpa y la sombra - una refutación de la "historia oficial" con una "historia adornada", especie de "ficción impura oscilante entre la realidad de la fábula y la fábula de la historia" que presenta un retrato más verosímil y más humano de un ser controvertido y mitificado.

La guerra del fin del mundo (1981), de Mario Vargas Llosa (1936), es un remake o una refundición de Os sertões de Euclides da Cunha a la vez que una ficción barroca y épica que narra la historia real de un falso profeta, cuya secta fanatizada se levantó contra la joven república brasileña. Por su parte, Historia de Mayta (1984) intenta reconstruir literariamente, haciendo converger en la reconstitución varios puntos de vista, la vida y las obras de un ex dirigente trotskista, Alejandro Mayta, protagonista de un conato revolucionario que abortó lastimosamente, en 1958, en el Perú de Manuel Prado.

Juan José Saer (1937) nos presenta en El entenado (1987) la ficción del grumete de una nave española, capturado por una tribu de antropófagos en un momento de la conquista de las Molucas. La obra, escrita en una lengua dúctil, elegante y poética, parodia picarescamente las viejas "crónicas de Indias".

Gabriel García Márquez (1928) pretende restituir en El general en su laberinto (1989) los últimos meses de la vida de Simón Bolívar y desmitificar o humanizar la figura del

\footnotetext{
"Fernando Ainsa, "La nueva novela histórica latinoamericana", y Claude Fell, "Histoire et fiction dans Noticias del imperio de Fernando del Paso", en Claude Cymerman (edit.), Le roman latinoaméricain des années 80, Les Cahiers du CRIAR (Publications de l'Université de Rouen, 1991).
} 
Libertador. Desgraciadamente, el respeto a la "verdad histórica" limita el campo de acción de García Márquez y no le permite dar libre curso a su imaginación mágica y a su vuelo poético.

\section{La crítica sociopolitica}

La mayor parte de la obra de Mario Vargas Llosa se apoya en las realidades de la sociedad peruana y cobra todas las apariencias de una crítica social. Esta crítica se expresó, antes de los años 70, con obras como La ciudad y los perros, La casa verde, Conversación en La Catedral. A partir de los años 70, Vargas cambia completamente de estrategia. Se ensaya en adelante en varios géneros, como si quisiera demostrar que su talento es universal o como si quisiera que su creación fuera una creación total. Se lanza así en la novela cómica (Pantaleón y las visitadoras, 1973), paródica (La tía Julia y el escribidor, 1977), histórica (Historia de Mayta, 1984), policíaca (¿Quién mató a Palomino Molero?, 1986), indigenista (El hablador, 1987) e incluso erótica (Elogio de la madrastra, 1988). Sin embargo, la crítica social aflora en todas esas obras, en particular en La tía Julia que hace burla, por una parte, de los "radionovelas" en que se solazan las amas de casa de Lima y, por otra parte, de las convenciones burguesas de la sociedad peruana.

Su compatriota Alfredo Bryce Echenique (1939) se dio a conocer con Un mundo para Julius (1970), seguido por La felicidad ja ja (1974), Tantas veces Pedro (1978), La vida exagerada de Martín Romaña (1981), El hombre que hablaba de Octavia de Cádiz (1985) y Laúltima mudanza de Felipe Carrillo (1988). El "mundo" de Bryce, mundo en gran parte autobiográfico, es tanto el de su infancia (el de Julius) como el del exilio peruano en París (el de Martín Romaña o el de Pedro Balbuena). La crítica social, tanto de la sociedad limeña como de la vida parisiense, se hace generalmente en un tono mordaz o distanciado y en un estilo que mezcla la ironía y el humor. Los personajes son a menudo excesivos o ridículos, cuando no son simples peleles erotómanos o dipsómanos.

De Gabriel Casaccia (1907-1980) se conocían sobre todo La babosa (1952), una extraordinaria sátira de la sociedad paraguaya, y Los exiliados (1966), otra sátira, la de los exiliados paraguayos que llevan en Posadas (Argentina) una vida de resentidos. Su última novela, Los herederos (1975), continúa esta crítica social en el estilo realista y sin concesiones que le conocemos.

David Viñas (1929) intentó reflejar en sus novelas la realidad sociopolítica de la Argentina desde la Independencia, desacralizando de paso a dos de sus integrantes, los latifundistas (Los dueños de la tierra, 1959) y los militares (Los hombres de a caballo, 1967). De su producción posterior a 1970 se destaca Cuerpo a cuerpo (1979), una novela urticante sobre el período peronista, escrita en un estilo seco, nervioso, violento, elíptico, críptico y sibilino a veces, capaz de pasar de la ironía a la ira, en aras de un mimetismo veraz y crudo.

Pedro Orgambide (1929) prosiguió en el exilio una obra empezada en los años 50. Ensayista y crítico literario (Borges politico, 1977), dramaturgo (Prohibido Gardel, 1978), poeta (Cantares de las Madres de Plaza de Mayo, 1983), escribió también prosa narrativa. Entre sus novelas destaca Hacer la América (1984), su libro probablemente más ambicioso. Ahí intenta darnos una visión global de la Argentina de principios del siglo XX, haciendo 
hincapié en los fenómenos vinculados con una ingente inmigración extranjera y poniendo de realce las luchas sociales y las relaciones entre criollos e inmigrantes.

Juan Gelman (1930), autor apasionado de Hechos y relaciones (1979), se interesa por gentes simples descritas en su quehacer cotidiano, a la vez que se levanta contra las exacciones y las atrocidades cometidas por la dictadura. Su estilo poético mezcla la sencillez del lenguaje hablado a la búsqueda de efectos metafóricos.

\section{El ensayo y la crítica socio-literaria}

Hay que confesar que en este campo los uruguayos descuellan singularmente. El exilio, además, les resultó —en el plano de la creación, se entiende- fructífero. Mario Benedetti (1920) escribió El escritor latinoamericano y la revolución posible (1974), El recurso del supremo patriarca (1979 — sobre la temática de la dictadura en tres novelas hispanoamericanas), Subdesarrolloy letras de osadía(1987) y La cultura, ese blanco móvil (1989); Fernando Ainsa(1937), que supo ojear la utopía en todas las culturas y civilizaciones, publicó Los buscadores de la utopía (1977), Identidad cultural de Iberoamérica en su narrativa (1986), Necesidad de la utopía (1990) e Historia, utopia y ficción de la Ciudad de los Césares (1992), así como un enjundioso ensayo sobre el exilio, De aquí y de allá (1991); Eduardo Galeano (1940) dió a la imprenta Las venas abiertas de América Latina (1971), Días y noches de amor y de guerra (1978) y una trilogía en forma de crónica sobre el continente americano, Memoria del fuego I, II y III(1982-84-86). A los aludidos hay que añadir además los nombres de Carlos Rama (1921), ensayista de Las ideas socialistas en el siglo XIX (1976), Sociología de América Latina (1977) e Historia de América Latina (1978), Emir Rodríguez Monegal (1921-1985), crítico de El Pais, autor de El boom de la novela latinoamericana (1972) y Borges, hacia una nueva poética (1976) y Ángel Rama (1926-1983), periodista de Marcha, que escribió Los dictadores latinoamericanos (1976) y Los gauchipoliticos rioplatenses (1982). Conocidas son las diferencias entre los dos últimos, que desembocaron en sonadas polémicas:

Ángel, más sociológico y político; Emir, más literario y académico; aquél más a la izquierda, éste más a la derecha. Las diferencias entre ambos uruguayos fueron providenciales, el origen de los más estimulantes torneos intelectuales a los que me ha tocado asistir. ${ }^{12}$

También Saúl Yurkiévich (1931) es un destacado ensayista que demuestra en su aproximación a los grandes poetas hispanoamericanos un rigor y una intuición poco comunes. Léase de él Fundadores de la nueva poesía latinoamericana (1971) - con estudios sobre Vallejo, Huidobro, Borges, Girondo, Neruda y Paz-Confabulación con la palabra (1978) y Littérature latino-américaine: traces et trajets (1988, en francés).

Otros prestigiosos hispanoamericanos publicaron ensayos que por sí solos les hubieran merecido la notoriedad. Citaremos sus principales aportaciones en este campo. De Cortázar son Territorios (1978), Nicaragua, tan violentamente dulce (1984) y varios textos sobre el

12 Prólogo de M. Vargas Llosa a La ciudad letrada (Hanover, New Hampshire: Ediciones del Norte, 1984) III-VIII. 
exilio; de Vargas Llosa, Historia de un deicidio (1971), La orgía perpetua (1975), José Maria Arguedas entre sapos y halcones (1978); de Donoso, Historia personal del "boom" (1972), etc., etc.

\section{El indigenismo}

Manuel Scorza (1928-1983) empezó escribiendo poesías - reunidas más adelante en Poesía incompleta (1976) - para luego dedicarse plenamente a una narrativa fundamentalmente social y política que defiende los derechos de comunidades indias abocadas a una situación de sometimiento feudal. Sus novelas, reagrupadas en un fresco cíclico titulado La guerra silenciosa - Redoble por Rancas (1970), Garabomboel invisible (1972), El jinete insomne (1975), Cantar de Agapito Robles (1976), La tumba del relámpago (1979) - aluden a menudo a episodios reales de la historia peruana. Son fundadoras, asimismo, de un nuevo indigenismo, continuador del de un José María Arguedas o un Ciro Alegría pero del que lo alejan la estructura narrativa resueltamente moderna, una atmósfera entre mítica y realista, un erotismo subyacente y un estilo épicolírico altamente sugestivo.

Como en La casa verde, Vargas Llosa hace converger en El hablador (1987) dos historias, dos personajes, que al final se reducen a la unidad. La novela cuenta la historia de un estudiante limeño que, fascinado por las culturas primitivas, intenta hacer revivir la tradición de los cuenteros o "habladores" indígenas y mantener viva la memoria de los indios machiguengas.

Con el indigenismo puede relacionarse la obra de Luis Sepúlveda (1950). En Un viejo que leía novelas de amor (1989), denuncia la destrucción salvaje, pero desarrollada en nombre de la civilización, de la selva amazoniana donde vive pacíficamente la tribu shuar. $\mathrm{Y}$ en $E l$ mundo del fin del mundo, disponible actualmente en su traducción francesa (Le Monde du bout du monde, 1983), defiende las soledades australes y las ballenas, amenazadas de muerte por la crueldad y el espíritu de rapiña de los piratas de hoy. La moderna afición ecológica no es, ni mucho menos, la única explicación de un éxito rotundo que debe sobre todo a la fuerza evocadora de las ficciones de Sepúlveda, a su carga de acción y de emoción y a un estilo a la vez conciso, pulcro y poético.

\section{La violencia}

América Latina ha sido marcada, desde su origen, por la violencia. Violencia de la conquista y de una colonización impuestas, violencia forzada de la Independencia, violencia de las revoluciones, los pronunciamientos o las patriadas, violencia de la llamada "guerra sucia", violencia de los opresores (latifundistas, gamonales, dueños de explotaciones) hacia los oprimidos (mineros, caucheros, yerbateros, chacareros), violencia de las condiciones de vida en las ciudades, violencia en las relaciones entre ambos sexos, etc. La violencia refleja desgraciadamente una situación social explosiva en países donde una minoría de poseedores y de oligarcas explota una mayoría de trabajadores míseros y hambrientos. No extrañará por lo tanto que la violencia aparezca como temática en muchas obras, y singularmente en la narrativa indigenista, en la novela de la dictadura y en la obra de Vargas Llosa, de Roa 
Bastos y de todos los autores que, en un momento u otro, han intentado reflejar en su creación la realidad hispanoamericana. Como lo señala Paul Verdevoye, "la violencia es inherente a la narrativa actual." 13 No daremos ejemplos porque sería repetir inútilmente títulos que hemos señalado ya o que vamos a señalar, pero sí volveremos sobre el tema en la tercera parte de este estudio, "La novela de la lucha armada y del exilio".

\section{El sexo}

La violencia aplicada al sexo se llama sadismo, sadomasoquismo, etc. Al revés de la violencia "pura", dicha temática no abunda en la literatura hispanoamericana. Tal vez el peso de la religión (al prohibir el placer físico y el erotismo), de la tradición familiar o social (al conceder una gran importancia a la preservación de las apariencias y al mantenimiento de ciertos tabúes), de las relaciones hombre/mujer o marido/esposa (en las que el varón asume una posición de predominio y se juzga mal cierta liberación de la mujer) han influido en la ausencia casi total del erotismo o de la pornografía en una literatura hispanoamericana influida, sin embargo, durante mucho tiempo, por una literatura francesa y europea en la que el sexo ocupa un lugar privilegiado. Citaremos sin embargo unas cuantas obras eróticas (o en las que se intercalan escenas eróticas) en las que la actuación de los protagonistas (a veces simple reflejo de la actitud del autor) parece indicar una voluntad deliberada de exorcizar o infringir los tabúes. El hecho de que estas obras sean todas modernas o, incluso, muy recientes parece indicar que las cosas están cambiando en este aspecto - para bien o para mal, no nos corresponde tomar posición en el asunto-y que, así como reaccionó contra las convenciones literarias, la "nueva novela" quiso reaccionar también contra los tabúes sexuales. En algunos casos, la sexualidad parece revestir una forma de rebeldía social y de liberación del individuo, como en El beso de la mujer araña (1976) de Puig o en Libro de Manuel (1973) de Cortázar. En otros, creemos que es el indicio de una nueva forma de encarar la vida y de buscar en ésta un epicurismo y un hedonismo como fuente de placer y justificación de la existencia. Cualesquiera que sean los motivos, la sexualidad y el erotismo empiezan a darse libre curso en la narrativa hispanoamericana. Para limitarnos a la novela rioplatense, podríamos asociar a las dos obras mencionadas: La vida entera (1981), de Juan Carlos Martini(1944), que intercala, en un relato protagonizado por proxenetas y prostitutas, momentos de sadismo y erotismo, Luna caliente (1983), de Mempo Giardinelli (1947), que describe los amores apasionados de un joven universitario por una nueva Lolita, Solitario de amor (1988), de Cristina Peri Rossi (1941), que detalla los fantasmas y las vivencias sexuales de un hombre perdidamente enamorado, y Amatista (1989), de Alicia Steimberg (1933). Amatista, publicada en la colección "especializada" de Tusquets, "La sonrisa vertical", novela realmente más pornográfica que erótica, trata de la educación sexual (no sentimental, a lo Flaubert) de un hombre casado pero desprovisto de imaginación, por una mujer liberada y, se adivina, muy imaginativa. Recordemos, por otro lado, que el mismo Vargas Llosa incursionó a su vez en el género erótico al publicar, en esa misma colección de "La sonrisa vertical", su Elogio de la madrastra (1988), que cuenta las relaciones entre ambiguas y perversas que median entre una mujer y dos hombres (padre e hijo). Otros

${ }^{13}$ Paul Verdevoye, Antologia de la narrativa hispanoamericana, Tomo I (Madrid: Gredos, 1979) 15. 
cultores del "sexo literario" son, para citar tan sólo los más famosos, Gabriel García Márquez que, en El amor en los tiempos del cólera (1985), cuenta las proezas eróticas de un Don Juan enamorado o Guillermo Cabrera Infante (1929) quien, en La Habana para un infante difunto (1979), recrea sus amoríos y sus experiencias sexuales habaneras.

\section{El humor}

Donald L. Shaw, citando precisamente a Cabrera Infante, recordaba que, hasta hace poco, la literatura latinoamericana pecaba por su seriedad y solemnidad. ${ }^{14}$ Las cosas han cambiado y puede decirse que, el día de hoy, el humor atraviesa, como una corriente subterránea, buena parte de esta literatura latinoamericana y que son pocos los escritores, incluso los más desesperados, que, en un momento dado, no han acudido al humor. El mismo Cabrera Infante ha dado muestras, en La Habana para un infante difunto (1979), de su humor lúdico y fantasioso, reforzado por un vertiginoso juego lingüístico o metafórico. Y no sólo él. El humor, la exageración grotesca, los excesos imaginativos y verbales, entran en la lista de los ingredientes que constituyen el "realismo mágico" de García Márquez. Sabemos que Vargas Llosa, en Pantaleón y las visitadoras y en La tía Julia y el escribidor, se ríe a cajas destempladas de los militares o de los fabricantes de "radionovelas". Conocido, por otra parte, es el humor desenfadado, rayando a veces en el absurdo, lo bufo-trágico o el humor negro, de Cortázar. Algo de este humor se encuentra en dos argentinas, Luisa Futoransky (1939) y Alicia Dujovne Ortiz (1940). La novela De Pe a Pa (1986) de la primera - este acertado juego lingüístico recubre la historia de una errancia que llevó a la autora de Pekín a París - aparte de que recoge experiencias amenas de sus vagabundeos, demuestra cualidades humorísticas naturales, consistentes en un acercamiento jocoso a hombres y cosas, en situaciones desopilantes o picantes y en una extraordinaria agilidad mental que desemboca en una lengua burlona y desfachatada. La segunda de nuestras escritoras hace gala en El buzón de la esquina (1977) y El agujero en la tierra (1980) de unas cualidades innatas que la llevan, por la magia de una lengua llena de colorido, a poetizar la realidad, sin dejar con todo de manifestar un humor risueño que se burla de las convenciones e insta a vivir el momento presente.

\section{El desencanto y la desesperanza}

Una de las modalidades del humor es el humor negro, que, se sabe, no es más que la máscara que oculta el escepticismo o el pesimismo del escritor. De hecho, la desesperanza es una de las marcas del hombre hispanoamericano moderno. Tal vez se deba, como en el caso de Donoso, a que el escritor trata de exorcisar sus angustias, sus demonios internos y un aparente sentimiento de culpabilidad. Tal vez esté inspirada en parte (como en el caso de Sábato) por la "náusea" sartriana. Tal vez también proceda, por lo menos en el Río de la Plata, de un estado anímico sombrío o nostálgico que viene reflejado ya en el tango. Tal vez (y es lo más probable) se deba a la inestabilidad de las instituciones democráticas y a la precariedad de la situación socioeconómica. El escritor ya no pertenece, como era el caso

\footnotetext{
${ }^{14}$ Nueva narrativa hispanoamericana (Madrid: Cátedra, 1981) 219.
} 
en el siglo pasado o en la primera mitad del nuestro, a las clases pudientes, indiferentes a las condiciones de vida de las clases sociales desfavorecidas. A menudo procede del pueblo, sufre con éste o por lo menos se muestra solidario del mismo. Es lógico, por lo tanto, que esta desesperanza se refleje en su obra, aun cuando tome la forma de la burla o de la irrisión.

No cabe duda que el máximo representante de esta desesperanza sigue siendo Juan Carlos Onetti (1909). Si bien escribió en Uruguay lo más enjundioso de su obra, compuso durante su exilio madrileño obras estimables como Dejemos hablar al viento (1979) y Cuando entonces (1987) en las que se observan rezagos de su producción anterior y un tono igual de pesimismo y desencanto, unos mismos cuadros de frustración y derrota. ${ }^{15}$

Esta disforia onettiana se vuelve a encontrar en Juan Carlos Martini. Este publicó dos novelas, La vida entera (1981) y Composición de lugar (1984), que reflejan, en su estructura laberíntica y en parte hermética, un desencanto "naturalista" con respecto al hombre presa del sexo y la violencia. De la primera, que se puede leer como una metáfora de la lucha por el poder en la Argentina, dijo Cortázar que ofrecía "una de las tranches de vie más intensas que un escritor argentino haya extraído de un sector mayoritario de nuestra realidad." La segunda expresa, a través de personajes que sufren un exilio exterior o interior, y en una forma que mezcla el hermetismo estructural con el enigma temático, el misterio de la mujer, la vida, la identidad, la lengua, el desarraigo.

\section{La nostalgia provinciana, el "paraíso perdido"}

Para Antonio Di Benedetto (mendocino, 1922-1986), Daniel Moyano (riojano, 19301992), Héctor Tizón (jujeño, 1929) y Gregorio Manzur (mendocino, 1936), representantes típicos de esta extraordinaria generación de escritores argentinos del interior, el exilio fue tanto más cruel que los alejó de este pedazo de tierra argentina donde encontraban su inspiración. Para los dos primeros, incluso, resultó excepcionalmente duro. En efecto, si a Di Benedetto, según lo cuenta él mismo, el trauma del exilio le produjo durante varios años un "disgrafismo" que le hacía confundir las letras de su máquina de escribir, por poco este mismo desarraigo termina con la carrera literaria del segundo que dejó de escribir durante casi cinco años. De Di Benedetto destacaremos los Cuentos del exilio (1983) y la novela Sombras nada más (1985). Los cuentos aludidos son, más que cuentos del exilio, cuentos escritos en el exilio, o en todo caso cuentos que reflejan un exilio interior y ontológico. La novela es una novela "onírica" en la que el autor vierte buena parte de las pesadillas que le proporcionaron los meses de encarcelamiento sufridos en la Argentina, al tiempo que aparece como una denuncia de todos los carceleros y torturadores engendrados por la dictadura militar. La conocida afición de Moyano a la música - y a la música de las palabras-así como su apego a la provincia argentina de La Rioja y su nostalgia del "paraíso perdido", se transparentan claramente en su narrativa, trátese de Libros de navíos y borrascas (de la que hablaremos más adelante) o de Tres golpes de timbal (1989) que plantea, poética y simbólicamente, la problemática de la identidad y la escritura. Héctor Tizón, por su parte, es el dulce cantor del noroeste argentino. En La casa y el viento (1984)

${ }^{15}$ En el momento de entregar este artículo para su publicación, nos enteramos de la reciente publicación en Madrid de Cuando ya no importe, la última novela de Onetti. 
reviven en la anticipación de un paraíso perdido, con una fuerza avasallante, impregnada de generosidad y solidaridad, gentes, paisajes, mitos jujeños en su autenticidad prístina, volcada a la escritura por una lengua a la vez dulce y rigurosa, fiel y poética. En cuanto a Manzur, cuentista de La garganta del águila (1977) y novelista de Solstice du jaguar (en francés, 1980), evoca lírica y sugestivamente recuerdos personales y restituye, con el alma de su región natal, mitos y leyendas indias.

\section{Lo ontológico y existencial}

Juan José Saer dio con El limonero real (1976) una obra maestra que narra la sencillísima historia de una humilde familia — dominada por la presencia obsesiva del hijo muerto- un 31 de diciembre, en una isla del Paraná. La humanidad de los personajes, la sensible evocación del lugar, los vaivenes del estilo, confieren a la narración un valor altamente poético y sugestivo. Las obras siguientes, Nadie nada nunca (1980) — con un obvio juego lingüístico en el título-Glosa (1986), cuyo argumento es la breve charla que intercambian dos jóvenes acerca de una fiesta de cumpleaños a la que ninguno de los dos pudo concurrir, El entenado (1988) -ya mencionada-La ocasión (1988), que cuenta la historia de un ocultista italiano inmigrado en la Pampa, confirman estas dotes excepcionales así como la virtuosidad con que Saer sabe construir el laberinto estructural de sus novelas. Mario Goloboff (1939) se dio a conocer primero con su novela Caballos por el fondo de los ojos (1976) que trata de la situación conflictiva de una familia judía emigrada, distendida entre el apego a la Argentina y la atracción de Israel. En la trilogía que vendrá después Criador de palomas (1984), La luna que cae (1989) y El soñador de Smith (1990)— que funda el pueblo mítico de Algarrobos, el protagonista vierte los recuerdos nostálgicos de su infancia y de su pueblo natal en un estilo lírico, lleno de simbolismo y de sugestividad, al mismo tiempo que plantea los problemas ontológicos y éticos con los que se debate la Argentina actual.

Cristina Peri Rossi, periodista y escritora, es conocida por sus poesías y libros de cuentos que resaltan por sus características de rigor, humor, sutileza y lucidez fría en su acercamiento existencial a la realidad de un mundo ajeno y a menudo hostil, en una espera desesperada del amor o del ideal. Solitario de amor (1988) nos hunde así en las aventuras, entre eróticas y frustrantes, de un hombre enamorado que choca con la indiferencia (o el ansia de independencia, o el temor a apegarse) de una mujer fatal.

De Julio Ramón Ribeiro (1929) destacaremos el ensayo Prosas apátridas ("completas", 1986) que, como la mayoría de sus obras, se señala por la crítica social, el desencanto existencial, el análisis psicológico sin concesiones, el humor cáustico, todo esto vertido a la literatura en un estilo conciso, pulido y eficaz.

Terminaremos con una alusión a la narrativa de José Donoso (1924), que se prolonga desde Este domingo (1966) hasta El jardín de al lado (1981), pasando por El lugar sin límites (1967), El obsceno pájaro de la noche (1970), Casa de campo (1978)o La misteriosa desaparición de la marquesita de Loria (1980). En toda su obra, reacciona contra un realismo que deja poco lugar a la expresión de sentimientos interiorizados y se vuelve hacia una forma de escritura que refleja mejor la angustia existencial del hombre. Parece llamar nuestra atención sobre la descomposición de la sociedad a la vez que da la impresión de 
poner en tela de juicio el mundo burgués al que pertenece y del que destaca los aspectos grotescos, repugnantes o enfermizos.

\section{El análisis psicológico, la autobiografia, la identidad}

Héctor Bianciotti (1932), autor inspirado de La busca del jardín (1977) y El amor no es amado (1982) donde destacan sutiles análisis psicológicos — a menudo autobiográficosasí como el hábil manejo de una lengua que refleja cual la de Proust los meandros del pensamiento, es el mejor exponente de esta corriente intimista. Hoy parece haber desistido de escribir en castellano. Después de adquirir, al igual que Cortázar, la nacionalidad francesa, compuso y publicó sus últimas obras — Sans la miséricorde du Christ (1985) y Ce que la nuit doit au jour (1992) - directamente en francés, lo cual representaría, según sus propias declaraciones, tan pronto "el exilio absoluto" como "el fin de un exilio".

\section{El realismo mágico}

Gabriel García Márquez nos cuenta que aprendió a conocer el continente americano en París por el gran número de exiliados latinoamericanos que residían en la capital francesa. Pedro Shimose señala, por su parte, que el escritor descubrió en el sur de Estados Unidos "la analogía entre el universo novelístico de Faulkner y la realidad del trópico hispanoamericano." Lo cierto es que toda la narrativa de García Márquez refleja maravillosamente —en los personajes, la atmósfera, la lengua, el humor- el mundo colombiano y caribeño. Si las últimas obras narrativas que siguieron a Cien años de soledad no tienen tal vez la fuerza sugestiva y el vuelo poético de esta novela, el "realismo mágico" sigue presente en El otoño del patriarca (1975), Crónica de una muerte anunciada (1981) y El amor en los tiempos del cólera (1985). Los Doce cuentos peregrinos (1992), a la vez que rematan unos viejos proyectos editoriales, inauguran una nueva etapa en la narrativa del escritor colombiano, en la medida en que dejan de lado el realismo mágico y abandonan el mundo colombiano y caribeño para enfrascarse en doce capitales o lugares del Viejo Continente. Excepto dos o tres fallos patentes, estos cuentos recuperan la vena y la inspiración típicas del autor de Los funerales de la Mamá Grande o de La increíble y triste historia de la cándida Eréndira.

Su compatriota Flor Romero de Nohra (1933) introduce en su narrativa(Triquitraques del trópico, 1972, Los sueños del poder, 1978) un realismo mágico que recrea las costumbres, creencias y supersticiones indias pero también la atmósfera y el contexto de violencia imperante en Colombia.

Con el realismo mágico, también, parece relacionarse Isabel Allende (1943). Si bien al empezar su carrera literaria con La casa de los espiritus (1982) -que mezcla lo maravilloso y lo fantástico con claras alusiones a la Unidad Popular y al golpe de estado de Pinochet- pudo aparecer como un epígono de García Márquez, encontró ahora su vía propia, perceptible en sus novelas De amor y de sombra (1984), Eva Luna (1987) y El plan infinito (1992), cuyas tiradas suelen alcanzar, en el mundo hispanohablante pero también en todos los países donde se traduce, cifras considerables. 


\section{El surrealismo y lo fantástico, la fantasia y el juego formal}

Difícilmente clasificables son las obras de Federico Undiano(1932) y Vicente Battista (1940), si bien la evocación de la locura o del fanatismo las acerca al surrealismo. El primero publicó en francés, bajo el título de Le chariot de foin ou le Mont Oméga (1984), una obra fuerte y original: nuevo "diario de un loco", la novela reivindica la "grandeza del delirio" y los "poderes poéticos de la locura" en una lengua a su vez poética y profundamente sugestiva. El segundo publicó en España dos novelas, Como tanta gente que anda por ahí (1975) y El libro de todos los engaños (1984). Esta última es un libro curioso y estimulante que cuenta misteriosa y simbólicamente la historia de los adeptos de una secta portadora de un doble secreto que no llega a esclarecerse del todo: la expulsión de uno de sus miembros y el contenido de un libro enigmático, "el libro de todos los engaños", precisamente.

El género fantástico tiene en Julio Cortázar (1914-1984) a su mejor representante. Instalado en Francia desde 1951, pasó muy pronto del estatuto de exiliado cultural al de exiliado político. Fue hasta su muerte (y aunque el Presidente Mitterrand le concedió en 1981 la nacionalidad francesa) algo como el decano de los exiliados latinoamericanos en París. No puede decirse que el exilio haya modificado profundamente el contenido y la forma de su escritura ya que Argentina sigue presente en su obra sin que su evocación se acompañe de una significativa nostalgia. De su prolífica producción posterior a 1970 entresacaremos Libro de Manuel (1973), Octaedro (1974), Alguien que anda por ahí (1977), Queremos tanto a Glenda (1981) y Los autonautas de la cosmopista (1983), escrito este último en colaboración con Carol Dunlop. En todas estas obras resalta lo que es en el autor de Rayuela una constante: investigación de la realidad con intromisión de lo irreal, introspección y análisis de los demás (y de sí mismo a través de los otros), afán de libertad y afición a lo lúdico (sin descartar la seriedad y a veces la angustia existencial), estructuras, estilo y lenguaje llenos de innovaciones y de fantasía.

Algo de estos juegos formales se encuentra en la poesía de Saúl Yurkiévich (1931). Es éste un esteta de la forma y un "gourmet" de la lengua que, al modo de un Apollinaire o de un Huidobro (a quien dedicó sendos ensayos), extiende cada vez más los territorios de la poesía. Fricciones (1969), Retener sin detener (1973), Acaso ocaso (1982), Trampantojos (1986) son buenos ejemplos de una producción que hace un lugar privilegiado al juego lingüístico y al esteticismo. Envers (edición bilingüe, 1980) y Soi-disant (en francés, 1990) son dos antologías que sintetizan los caracteres de una poesía plurivalente que, solicitando los cinco sentidos y procurando adecuar forma y contenido, intenta descubrir lo más ontológico y vivencial.

Un prodigioso malabarista de las palabras es Guillermo Cabrera Infante cuyos vertiginosos juegos formales en forma de trabalenguas, retruécanos, trastrocamientos, paronomasias, esmaltan sus recreaciones y fantasías habaneras. Compatriota suyo es Severo Sarduy (1937-1993), del que se conocen sobre todo sus novelas Cobra (1972), Maitreya (1978) y Colibri (1984). Amigo de Barthes y de Sollers, miembro del grupo "Tel quel", se lanza en juegos y experimentos estructurales y formales de los cuales Cobra, historia de un travesti, contada en un estilo entre barroco y surrealista, es tal vez el ejemplo más significativo y más brillante. 
Comprobamos, después de este rápido bosquejo de la literatura escrita en el exilio, que las tendencias y las expresiones de dicha literatura no quedan muy alejadas de las manifestaciones de la creación en el propio país. A lo más se hacen más insistentes en la literatura escrita en el exilio las expresiones de la nostalgia y del ansia de retorno, el repliegue sobre sí mismo, lo punzante del recuerdo o el interés manifestado por la lengua. Pero la creación sigue siendo en su conjunto inconfundiblemente latinoamericana. Siguen imperando, por lo común, las modalidades libertarias de la "nueva novela" con un claro rechazo a las convenciones literarias y a cualquier forma de estructuración normativa. Se insinúa incluso una adecuación entre el mundo real y el mundo de la ficción en la medida en que la desestructuración de la novela semeja la desestructuración del mundo y la subversión de la técnica literaria refleja una subversión contra el orden establecido. Las diferencias son limitadas y se relacionan principalmente con la (falta de) libertad de expresión. Señala Beatriz Sarlo que "una zona importante de la literatura argentina (escrita y publicada en el país o en el exilio) puede ser leída como crítica del presente, incluso en los casos en que su referente primero sea el pasado." ${ }^{16}$ Creemos que la observación se puede generalizar a la literatura hispanoamericana y que es cuanto más valedera que se aplica a la literatura publicada bajo la dictadura donde, obviamente y a diferencia del exilio, imperaba la censuray se daban las condiciones de una "cultura del miedo". El terror institucionalizado explica que, a diferencia de la literatura del exilio, libre y explícita, la literatura bajo la dictadura sea a menudo una literatura críptica y codificada. Las demás características, en cambio, nos parecen comunes a la literatura escrita dentro y fuera del país durante el "Proceso": una tendencia frecuente a insertar en la obra (explícita o implícitamente) un mensaje o una denuncia, cierta afición a la caricatura y a la parodia, un interés renovado por la historia, una interrogación lancinante de tipo ontológico o sociológico, la expresión frecuente del desencanto o del pesimismo, la omnipotencia de la violencia. Cualquiera que sea, "interior" o "exterior", la literatura de los años 70 y 80 se ciñe cuanto más a su época y se implica cuanto más que ésta es una época turbia y turbada en la que la vida humana y la identidad nacional quedan fragilizadas y fragmentadas, y en la que la historia se está convirtiendo en una tragedia donde cada uno se ve involucrado e interpelado.

\section{LA LITERATURA DE LA LUCHA ARMADA Y DEL EXILIO}

Esta tragedia, obviamente, queda todavía más presente en la literatura del exilio propiamente dicho que es la que vamos a estudiar ahora. Por razones que caen de su peso, el tema del exilio se mezcla a menudo, íntimamente, con otro tema que lo explica y lo implica, el de la lucha armada, la violencia y la represión. El tratamiento obedece evidentemente a muy diversas intenciones y su praxis da lugar a tendencias diferentes, divergentes inclusive, que nos ha parecido oportuno clasíficar y ordenar en función de la problemática elegida:

\footnotetext{
16 "Política, ideología y figuración literaria", en Ficción y politica. La narrativa argentina durante el proceso militar (Buenos Aires: Alianza Editorial, 1987) 34.
} 
1. Obras que denuncian el terrorismo de estado y la actuación de las fuerzas militares

La denuncia del comportamiento de los militares tiende, no sólo a patentizar la realidad de un terrorismo de estado, sino a refutar la propaganda oficial y a restablecer, para la opinión nacional e internacional, la verdad de los hechos.

El vuelo del tigre (1981) de Daniel Moyano (1930-1992) aparece como una metáfora de la tiranía, con claras referencias a la dictadura nazi y, también, argentina. El desenlace, felizy alegórico de la novela, es la expresión, si no del optimismo del escritor, por lo menos de su fe en su propio mundo y de su generosidad incomensurable : el "vuelo" de Nabu, el tirano, es, en suma, la resultante metafórica del vuelo poético de Moyano.

Humberto Costantini (1924) se ha interesado en los problemas existenciales y cotidianos que atañen al hombre común, al "antihéroe" si se quiere. En De dioses, hombrecitos y policías (1979), una novela que desarrolla en paralelo tres puntos de vista narrativos, imagina a un grupo de poetas que se reúnen semanalmente para leerse mutuamente sus versos, inconscientes de la amenaza que la dictadura militar y las policías paralelas hacen pesar sobre ellos. Por su parte, el protagonista de La larga noche de Francisco Sanctis (1984) no tiene nada a priori que parezca predestinarlo a ser un héroe. Modesto oficinista, casado y con tres hijos, se preocupa más de la armonía de su hogar o de satisfacer sus pacíficas aficiones musicales que de lucha armada o de revolución. Sin embargo, el peligro que se cierne sobre una pareja de jóvenes militantes al que sabe que van a detener las fuerzas armadas para torturarlos y matarlos, y el peso de su conciencia de hombre bueno, termina haciendo de él un auténtico héroe.

Cuarteles de invierno (1982), de Osvaldo Soriano (1943), tiene por protagonistas a un boxeador y un periodista, dos pobres diablos, entre héroes y antihéroes, que luchan patéticamente por sus derechos antes de caer derrotados por la fuerza brutal y aterradora del ejército y de la dictadura. La novela, escrita en un estiloágil y coloquial en el que predomina el diálogo vivaz, no desprovisto de humor e ironía, es una clara denuncia de las exacciones perpetradas por los militares durante el "Proceso".

Mempo Giardinelli se vale de un estilo sobrio, incisivo, sugestivo para tratar en $L a$ revolución en bicicleta (1980) y Qué solos se quedan los muertos (1986) el tema de la dictadura militar, la violencia y el exilio. Esta última novela se presta a una doble lectura. Si por un lado adopta los códigos y el ritmo de una novela policial (un exiliado argentino investiga en Zacatecas sobre un asesinato), por otro lado puede leerse como un testimonio sobre una doble violencia - la de la lucha armada y la represión en la Argentina, la del medio de la droga en la ciudad mexicana de Zacatecas donde se desarrolla la acción-y sobre las desviaciones del exilio argentino en México.

Miguel Otero Silva (1908) publicó a principios de los 70 una novela sobre el tema de la violencia socio-política en Venezuela, Cuando quiero llorar no lloro (1970). La novela desarrolla en forma paralela tres relatos, protagonizados los tres por un joven que lleva el mismo nombre, antifrástico e irrisorio, de Victorino. En los tres casos, en efecto -el estudiante torturado por la policía, el delincuente abatido después de un asalto, el burgués que quiso salir de su mundo-el joven sale derrotado. 
Carlos Martínez Moreno (1917-1986), que nutrió sus novelas de sus experiencias de periodista y abogado, prosiguió en su exilio mexicano su lucha por la democracia y los derechos humanos al publicar El color que el infierno me escondiera (1981) que condena a la vez la barbarie de los militares - asesorados por las fuerzas especiales estadounidenses, que torturan y matan a inocentes y desgraciados-y los excesos fanáticos de los guerrilleros.

Mario Benedetti (1920) incluye en Geografias (1984) cuentos precedidos por otros tantos poemas. Todos, cual más cual menos, evocan, con un realismo templado por el humor, las atrocidades cometidas por los militares uruguayos, pero también la nostalgia, el desarraigo, la depresión, el rencor, en fin, todos los males que llegan a constituir lo que el mismo Benedetti llamó en otro lugar "las siete plagas del exilio".

\section{Obras que exaltan la lucha armada y ponen de ejemplo a los revolucionarios}

Por su parte, el protagonista de otra novela benedettiana, Primavera con una esquina rota (1982), un tupamaro recluido en una cárcel uruguaya vive una trágica soledad, apenas compartida por otros detenidos políticos tan desamparados como él. Sin embargo, su moral sigue intacta y parece incluso haber escapado, por su valor y entereza, de la empresa sistemática de destrucción físicay mental de los prisioneros políticos, confesada cínicamente por algunos mandos militares. Su mérito es cuanto mayor que fue torturado en forma salvaje, sin que llegara en ningún momento a denunciar a sus compañeros de lucha. Podría aparecer por lo tanto como el prototipo del guerrillero "dinámico, optimista y vital". Pero, si por esas características se identifica con un auténtico "héroe", sin embargo, las vicisitudes de su vida privada (su mujer lo engaña con otro ex guerrillero) y el mismo fracaso de su experiencia revolucionaria —equiparada además a un "error" juvenil-implican ya cierta negativización del héroe.

3. Obras que tratan del peronismo y de la lucha entre montoneros y partidarios de López Rega

Osvaldo Soriano, ya nombrado, ficcionaliza en No habrá más pena ni olvido (1980) la lucha de la democracia y del conservadurismo, a la vez que denuncia las masacres cometidas, a la vuelta de Perón, por los adictos a López Rega contra las juventudes peronistas de izquierda.

Estas rivalidades mortíferas en el seno del peronismo vuelven a ser argumento narrativo en La novela de Perón (1985) del periodista Tomás Eloy Martínez (1934). Al presentarnos a un Perón vanidoso, egoísta, insensible, falso, desleal, retorcido, demagogo, oportunista, cínico, cobarde, acentúa la desacralización y desmitificación de un hombre aparentemente providencial pero convertido realmente en antihéroe. En todo caso, si heroísmo hubo en el justicialismo, fue el de los jóvenes peronistas que arriesgaron sus vidas por un individuo que nunca supo dar la cara. Es obvio, tanto en Soriano como en Martínez, el maniqueísmo justiciero y la voluntad de quitarle la máscara a la impostura. 
4. Obras que se interrogan sobre las causas del fracaso de la lucha armada asi como sobre la validez de los conceptos revolucionarios

Estanegativización aparece más evidente todavía en La nostalgia tiene bolsillo (1985) de Leo Harari. La novela representa el heroísmo de cada instante de los guerrilleros que han participado en la revolución tupamara. Al principio, ésta suscita una adhesión sin límites. Luego, poco a poco, la duda se insinúa en la mente del principal protagonista de la novela, que parece haberse inspirado de la actuación guerrillera del mismo autor. El entusiasmo, el valor, la generosidad, la abnegación heroica que admiraba al principio en sus compañeros de lucha, se empañan en adelante de maniqueísmo y de sectarismo. El puro héroe da paso al dogmático puro y duro. Y si la causa sigue siendo admirable, sus celebrantes, otrora idealizados, resultan ahora desacralizados.

Vimos con qué fuerza Carlos Martínez Moreno llegó a combatir las atrocidades cometidas por militares uruguayos. Pero, en su afán de imparcialidad y de justicia que corresponde a sus antiguas funciones de abogado y de periodista, no pone menos fuerza en denunciar los excesos cometidos por algunos revolucionarios al contarnos un episodio que, al parecer, extrajo de la realidad. El episodio, incluido en El color que el infierno me escondiera, es el siguiente: un campesino, en busca de un potrillo escapado, descubre por casualidad la tatucera (escondrijo) de unos tupamaros. Aquellos lo detienen y, al no saber qué hacer con él, deciden consultar a los dirigentes montevideanos del movimiento. En el temor de que el campesino los traicione si lo sueltan, los dirigentes lo condenan a muerte. Poco después se le ejecuta con una inyección de pentotal. Con este epílogo, Martínez Moreno denuncia la cruel y absurda contradicción incluida en el hecho de que se llega a matar a inocentes a favor de los cuales, teóricamente, se está luchando.

Al margen de sus novelas indigenistas, Manuel Scorza (1928-1983) escribió La danza inmóvil (1982), que hubiera podido subtitularse muy bien "El conflicto del amor y del deber revolucionario". Amor y revolución parecen ahí radicalmente incompatibles. La novela opone, en una dicotomía dialécticamente llevada, un héroe de la Revolución, para quien la lucha armada es el único objetivo legítimo, y un ex revolucionario, apartado de la lucha por el amor a una mujer. Al final de la novela, cada uno de los personajes piensa que el otro ha sabido elegir mejor. De paso, el novelista denuncia implícitamente todo lo que puede haber de rigor romano y, digámoslo, de fanatismo, en los revolucionarios, quienes aparecen desde ese momento como héroes mecánicos que sustituyen el ideal a los sentimientos.

\section{Obras que condenan el machismo de los revolucionarios}

Esta misma desacralización del héroe la volvemos a encontrar en Manuel Puig (19321990). En El beso de la mujer araña (1976) ataca a la dictadura, denunciando las torturas y las exacciones del poder militar. Ahí, como más tarde en Pubis angelical (1979), demuele un doble mito: el del "macho" valeroso y fuerte, y el del revolucionario respetable en su idealismo. Parece como si Puig, al tiempo que desmitificaba o demistificaba el ideal revolucionario, hubiera querido desenmascarar a sus falsos héroes. En la mejor hipótesis, los revolucionarios son, para él, unos románticos ingenuos; en el peor de los casos, unos aventureros sin demasiados escrúpulos para quienes el fin siempre justifica los medios. El 
cinismo y el maquiavelismo parecen constituir la esencia de la personalidad de esos antihéroes y de esos falsos duros.

\section{Obras que aparecen como una burla o una parodia de la revolución}

Aquí también se lleva Argentina, si puede decirse, la mejor parte. El primero en haber tocado el tema es sin duda Julio Cortázar en Libro de Manuel (1973). De hecho, la lucidez desencantada del autor de Rayuela y su afición al humor y a la irrisión aleja la obra de cualquier forma de hagiografía o de idealización de la lucha armada. Al revés, Libro de Manuel aparece sobre todo, por un lado, como una burla a expensas de la militancia y de la lucha armada, y, por otro lado, como una desacralización humorística de los actores de la revolución, los cuales desempeñan sobre todo un papel de bromistas o de farsantes, más a sus anchas en sus diversiones o asuntos de cama que en la lucha armada y en la ascesis revolucionaria. Semejante burla a expensas de la revolución, que asomaba ya en Puig, se vuelve a encontrar en Asís y en Mendoza, por ejemplo.

\section{Obras que se burlan de los exiliados, asemejados a "revolucionarios de salón"}

Es sin duda Años de fuga (1979), de Plinio Mendoza (1932), la novela más lúcida y más desencantada que se haya escrito sobre la revolución y el exilio. Los héroes -en el doble sentido de la palabra- de La danza inmóvil no tenían más elección que la guerrilla en la selva tropical o el exilio (dorado) en París. Las primeras páginas de la novela de Mendoza limitan igualmente la elección: "París o la selva, no hay otra alternativa." El dilema, lo vemos, sigue siendo el mismo. De hecho, la novela parece englobar en una misma reprobación, por un lado, la "ilusión lírica" de los revolucionarios, su infantilismo y, también, su fanatismo; $\mathrm{y}$, por otro, las teorías huecas o hueras de los revolucionarios de salón. Unos fraguan "héroes" insensibles, intransigentes e implacables; otros unos antihéroes instalados en su conforty su aburguesamiento. El compromiso militante aparece entonces como un pecado juvenil, las poses y las actitudes de los exiliados o ex revolucionarios que se quedaron en el país de acogida como una impostura o una negación del ideal.

Los personajes de El jardín de al lado (1981), de José Donoso (1924), son, con alguna que otra honrosa excepción, unos mediocres que se pasan el tiempo añorando e idealizando el antes y el allá y tratan de sobrevivir, fracasando unos a causa de su incapacidad o triunfando otros gracias a su oportunismo. La novela es sin duda la más característica, la más típica del tema: exilio político y cultural, características y consecuencias, tanto materiales como morales, de este exilio, vida y vicisitudes de los exiliados, trauma y "duelo", relaciones con el otro o consigo mismo, problemas de identidad, conflictos entre padres e hijos, todos los ingredientes propios del género se encuentran reunidos allí.

Una última novela, El pretexto de París (1986), de Jorge Asís (1946), llama nuestra atención. Asís, es cierto, nunca vivió en el exilio. Pero trató el tema y creemos que, por lo tanto, merece que se le haga un lugar en este estudio. La obra aludida, sin duda la más iconoclasta de la serie, es una carga acerbay caricaturesca contra, a la vez, los revolucionarios desfasados, ingenuos o utópicos, los revolucionarios de salón, y los oportunistas que sacan 
provecho de la revolución. En su desmitificación del heroísmo usurpado, el autor se vale - como en muchas de sus novelas - de todas las armas de la irrisión y de la rechifla.

\section{Obras que hacen de los revolucionarios unos fracasados}

Maldición eterna a quien lea estas páginas (1980), otra novela de Manuel Puig, presenta la vida cuasi vegetativa de un ex prisionero de la dictadura argentina, exiliado en los Estados Unidos para ser tratado allí por una organización de ayuda humanitaria, impedido en lo físico y disminuido mentalmente a consecuencia de su encarcelamiento y de las torturas sufridas. Puig hubiera podido hacer de él un héroe de la revolución. En lugar de esto, ha creado un personaje insustancial, maniaco depresivo, cuyo comportamiento no sugiere más que el fracaso y la decrepitud.

El tema del inválido, perceptible en Maldición eterna, lo recoge complacido Rodolfo Rabanal (1940). Al lado de los tres protagonistas narradores de En otra parte (desdoblado en "Nueva York es un nervio desnudo" y en "Días de gloria en Medora", 1981) y de El pasajero (1984), unos fracasados ociosos o amargos, se encuentran en efecto otros tres personajes achacosos o cacoquímicos, de los cuales uno, un ex combatiente de Viet-Nam, terminará levantándose la tapa de los sesos. En Rabanal, el marco y el paisaje circundante, cuasi onettianos, constituidos por la lluvia diluviana o el calor canicular, por la fealdad de las construcciones y el desaliño de los habitantes -exiliados e inmigrados inclusiveenfrentados con las desgracias y los achaques continuos, allí todo rezuma el aburrimiento y el miedo, todo respira el desencanto y la mezquindad, todo evoca la derrota y la decadencia.

\section{Obras que presentan el exilio de mediocres o de personas insignificantes}

Dijimos que íbamos a hablar tan sólo de las obras publicadas en los 70 y en los 80 . Haremos una excepción con Los exiliados (1966) de Gabriel Casaccia (1907-1980), por ser esta novela la única en evocar el exilio paraguayo, a pesar de la extensión y la crueldad de la dictadura stroessneriana. Bajo su título emblemático, nos ofrece la visión desalentadora de seres fofos e inermes, veleidosos y pusilánimes, hundidos en la chatura de un exilio inactivo, bajo el sol agobiante de la ciudad de Posadas. Más que de acción, viven de recuerdos, y aún de recuerdos deformados y exagerados por el tiempo y la megalomanía. Parasitismo, embriaguez, cafishismo, afición a la vida pendenciera y prostibularia, y también mezquindad, ruindad, indignidad, son las características más comunes de esos infelices menoscabados por el exilio. Muy pocos se salvan en este retrato sin concesión ni esperanza. Los exiliados aparece como la novela paradigmática de los mediocres y de la mediocridad, de los antihéroes y de la antiheroicidad.

Cae la noche tropical (1988), la última novela de Puig, si bien no alude a la lucha armada, se mantiene en la temática del exilio al contarnos las historias de tres mujeres exiliadas en el Brasil, entre la decrepitud y el desamor. 
10. Obras que presentan una visión fundamentalmente nostálgica, vinculada a menudo con el tema de la identidad

Muy diferente es el tratamiento del exilio en Con acento extranjero (1984) de Fernando Ainsa (1937). El protagonista, hijo de un republicano español emigrado a Chile, tiene que exiliarse a su vez después del golpe de Pinochet. Lo encontramos así en España en busca del recuerdo de su madre (fallecida cuando él tenía tan sólo siete años) y de sus propias raíces. De todo ello trasciende un tono a menudo nostálgico, lleno de ternura y emoción, pero siempre sereno, sosegado, templado por una mezcla de pudor y de humor que lo hace siempre ameno y conmovedor.

La narrativa de Antonio Skármeta (1940) -Soñé que la nieve ardía (1975), No pasó nada (1980) y Ardiente paciencia (1986) - señala su nostalgia de Chile y su emoción ante los avatares sufridos por el pueblo chileno. Su novela corta No pasó nada cuenta, en un lenguaje sencillo y mimético, impregnado de emoción y de ternura, las tribulaciones de un adolescente chileno exiliado en Alemania. En el trasfondo se desdibuja la tragedia de un Chile ahogado por la dictadura.

Como Libro de Manuel, Vudú urbano (1985), de Edgardo Cozarinsky (1939), es otra novela que transporta a los personajes y al lector de una capital a otra. En esta obrita de poco más de cien páginas, el escritor presenta, en unas viñetas que él llama "tarjetas postales", unas cuantas vistas cinematográficas de Buenos Aires y de París, confundidas las dos ciudades en una misma visión teñida de nostalgia y humor.

Rubén Bareiro Saguier (1930) es autor de cuentos (Ojo por diente, 1972, El séptimo pétalo del viento, 1984) en los que expresa, con aguda sensibilidad, los sufrimientos de los oprimidos y la nostalgia de la tierra natal.

Alicia Dujovne Ortiz publicó últimamente $L$ 'arbre de la gitane (en francés, 1991), una novela parcialmente autobiográfica sobre el tema del exilio.

\section{Obras que plantean problemas ontológicos o existenciales}

En un registro totalmente distinto, Libro de navios y borrascas (1983), de Daniel Moyano, opone dos categorías de antihéroes: por un lado, unos setecientos indeseables anónimos transportados, camino del exilio, por el Cristóforo Colombo, hundidos todos en su desconcierto y su fracaso existencial, y por otro, sus verdugos, los militares argentinos, cuyas tristes hazañas se sitúan en las antípodas de los "valores" guerreros tradicionalmente reconocidos. La novela pone de manifiesto la derrota que representa el exilio, derrota que se opone a la voluntad de vencer que habitaba a los inmigrantes que supieron otrora afincarse en el suelo argentino. El desencanto que implica la concientización de este fracaso viene templado, felizmente, por un sentido del humor permanente en Moyano y por una lengua extraordinariamente dúctil, sabrosa, cargada de imágenes y musicalidad.

\section{Obras que atacan al régimen de Fidel Castro}

Último país de nuestra recensión, Cuba ha condenado al exilio a muchos de sus escritores, en una proporción comparable con la observada en los países del Cono Sur pero, 
claro está, por razones políticas inversas. El poeta Heberto Padilla (1932) fue el primero en sufrir los efectos del sectarismo janoviano que empezaba apredominar entre los representantes oficiales de la cultura cubana. A pesar de haber adherido a los objetivos de la revolución cubana, la publicación de Fuera del juego (1968), un libro de poemas en el que denuncia algunos abusos o excesos del nuevo poder, le merece el ostracismo del gobierno castrista que, en 1971, llegó a encarcelarlo y a someterlo a una humillante autocrítica de tipo estaliniano. Se habló en esta ocasión del "caso Padilla" en el que intervinieron unos cincuenta escritores (entre ellos Jean-Paul Sartre), sin que estas intervenciones llegasen a impedir las persecuciones y la prohibición de sus obras en Cuba. En 1980 fue García Márquez quien intervino a su favor y consiguió que Castro le permitiese exiliarse a los Estados Unidos. La poesía de Padilla destaca por su sencillez y su sobriedad, igualmente alejadas de efectos metafóricos y rítmicos. En el exilio publicó una novela, En mi jardín pastan los héroes (1981), una sátira de la dictadura castrista y una reflexión sobre la condición del intelectual, y una autobiografia que alude a las desviaciones de la revolución cubana, La mala memoria (1991).

Otros escritores cubanos exiliados son Armando Valladares, Jorge Valls, Reynaldo Arenas, Guillermo Cabrera Infante y Severo Sarduy. Armando Valladares (1937), encarcelado durante más de veintidós años por el régimen cubano (de 1959 a 1982) y liberado, al parecer, gracias a la intervención de Arrabal, denuncia en un panfleto traducido al francés, Mémoires de prison (1986), la vigilancia, la delación, la represión y los trabajos forzados en las penitenciarías cubanas. Jorge Valls (1939), poeta y filósofo, pasó la mayor parte de su vida en la cárcel o los campos de concentración (veinte años, de 1964 a 1984) y, ahora, en el exilio. En Mi enemigo, mi hermano (1989) cuenta su vida y la de todos los prisioneros políticos encarcelados que, sin embargo, habían en su tiempo consagrado su vida a favor de la revolución. Reynaldo Arenas (1943-1990) vivió desde 1980 exiliado en Estados Unidos. De su obra narrativa publicada en el exilio destacan El palacio de las blanquísimas mofetas (1980), Otra vez el mar (1982), Arturo, la estrella más brillante (1984), El portero (1988), La loma del ángel (1989), Viaje a La Habana (1990). Antes de exiliarse había sufrido las misma vejaciones que Padilla al prohibírsele la publicación en Cuba de $E l$ mundo alucinante, especie de parodia de hechos históricos relacionados con la realidad cubana. El ciclo novelesco de Arenas, así como muchos de sus personajes, reflejan el pasado histórico cubano, desde el "prebattistato" hasta la época que siguió a la revolución. (El portero, por su parte, aborda el tema del exilio.) Arenas es un rebelde que no acepta las normas políticas, morales, estéticas impuestas por el régimen castrista. Sus personajes, antes de sucumbir, reaccionan contra la sociedad implacable que los aplasta. De su escritura dice Liliane Hasson:

En una lengua suntuosa, lírica, se expresan un erotismo desenfrenado, una truculencia rabelaisiana, una imaginación delirante, un humor y una causticidad que no perdonan a nadie, ni siquiera al mismo autor. ${ }^{17}$

Arenas, atacado de Sida, se refugió en el suicidio.

${ }^{17}$ Le Monde (París, 11 de diciembre de 1990). 
(Recordaremos, como curiosidad, que Jorge Edwards [1931], que durante el gobierno de Allende había desempeñado funciones diplomáticas en Cuba, fue expulsado de aquel país al criticar en un libro autobiográfico, Persona non grata [1973], el gobierno castrista.)

Hemos podido comprobar que - salvando el caso de la narrativa cubana - la novela de la lucha armada y del exilio ha engendrado una auténtica galería de héroes controvertibles, que van desde el militante puro y duro hasta el miles gloriosus, pasando por los avatares intermediarios del héroe decaído o del falso héroe: usurpadores, traidores, minusválidos físicos o mentales, aburguesados, Don Juanes.

El exilio es esencialmente desmobilización. El exiliado revolucionario depone las armas. Pero el "héroe", hombre de acción por excelencia, presa de una necesidad visceral de actividad, tiende a sustituir una empresa a otra. En el caso presente, es hacia el bello sexo que se muestra más emprendedor. Al deponer las armas de la guerra, toma las del amor. Venus, o Eros, ocupan en adelante el lugar de Marte. A la guerra sucede el descanso del guerrero. El soldado desmovilizado se entrega a las delicias de Capua. Las hazañas militares se convierten en proezas eróticas. Los puros héroes revolucionarios sin trabajo se hacen los campeones (algo) pervertidos del amor. Se conducen, en este terreno, como verdaderos tácticos y técnicos del amor. Sus asaltos eróticos sacan provecho de la estrategia militar que fue la de la revolución. En este aspecto, la victoria está (casi) siempre a la vista. Sus conquistas femeninas, por su parte, son siempre en la ficción unas mujeres jóvenes, bellas, sexy. El "héroe", ex héroe o antihéroe, les permite realizarse y, al revelarles el amor verdadero, las revela a sí mismas y hace de ellas unas mujeres cumplidas. No pocas veces, incluso, retribuyen al héroe con su satisfacción agradecida.

¿Por qué - cabe preguntarse - esta degeneración del héroe original?

1. Ante todo, porque éste es un perdedor, un loser - como dicen los norteamericanosy porque, por este mismo hecho, pierde el resplandor, el prestigio, el carisma que sólo se mantienen en los héroes cuando la muerte los ha fijado, cuajado, petrificado, haciéndolos eternos e inalterables.

2. Porque esta revolución frustrada es considerada como un fracaso colectivo, particularmente desvalorizante.

3. Porque el personaje de ficción, el protagonista, el narrador, que se inspiran a veces del autor y pasan así del estatuto de figura autodiegética al de figura autobiográfica, experimentan también este fracaso como un fracaso individual.

4. Porque el alejamiento espacial de las fuentes de la revolución y la fractura producida en la integración en la comunidad militante han apagado la exaltación de la lucha y el fervor revolucionario.

5. Porque el escritor-demiurgo, al crear su ficción, a menudo, varios años después de una época revolucionaria en la que ha participado directa o indirectamente, ha envejecido $\mathrm{y}$, con el distanciamiento temporal, tiende a considerar su compromiso como un error juvenil.

6. Porque el escritor se ha aburguesado, contagiando lógicamente a su creación.

7. Porque el personaje del héroe se considera desde el exilio que hace de filtro deformante o "negativizante".

8. Porque el fracaso de la revolución frustrada se aumenta de un segundo fracaso, el del mismo exilio, acerca del cual todos los psicólogos y psicoanalistas han demostrado todo lo que llevaba de desvalorizante y de deprimente para el individuo. 
9. Porque, en fin, la epifanía de los héroes y martirios de la realidad histórica ha engendrado al nivel de las masas pasivas, resignadas o no comprometidas, una mala conciencia, incluso un sentimiento de culpabilidad en el que entran a la vez la sensación de haberse quedado atrás, cobardemente, con respecto al "héroe" y la impresión de haber contribuido en parte a su caída. Porque esta autoculpabilización, frecuente entre los exiliados, ha contagiado a los creadores exiliados y, por vía de consecuencia, ha producido en la literatura del exilio un deterioro de la imagen del héroe.

Así, el paradigma de la lucha revolucionaria, prestigioso y ejemplar en su pureza de cristal, ha venido a ser, con el fracaso de la lucha armada y el escepticismo iconoclasta del escritor exiliado, un modelo devaluado e impuro, lastimoso o cínico, fracasado o libertino: en resumidas cuentas, un héroe adulterado, decaído, venido a menos, una parodia de héroe, un antihéroe $\mathrm{o}$, cuando menos, un ahéroe.

\section{CONCLUSIÓN}

García Márquez insiste sobre todo lo que el mestizaje cultural aportó a la elaboración de la identidad latinoamericana y a su expresión en la literatura:

En el Caribe, al que pertenezco, se mezcló la imaginación desbordante de los esclavos negros africanos con la de los nativos precolombinos y luego con la fantasía de los andaluces y el culto de los gallegos por lo sobrenatural. Esa aptitud para mirar la realidad de cierta manera mágica es propia del Caribe y también del Brasil. [...] Yo creo que el Caribe me enseñó a ver la realidad de otra manera, a aceptar los elementos sobrenaturales como algo que forma parte de nuestra vida cotidiana. ${ }^{18}$

Algo comparable se ha producido con el exilio. Al superponer dos experiencias o dos realidades, las del país de origen o las del país de adopción, a menudo el escritor ha sabido comunicar a su obra una mayor humanidad que le ha permitido sobrepasar el estadio de lo nacional espaciotemporal para alcanzar lo universal y eterno: es el caso, por ejemplo, de una novela como Hijo de hombre que, situada en el corazón de la realidad paraguaya, proyecta a sus protagonistas en una perspectiva humanista y cósmica. Sin embargo, se sabe que toda la obra en prosa de Roa Bastos ha sido elaborada en el exilio argentino y francés. Por otro lado, ¿cómo seguir hablando de una realidad nacional cuando se alude a la vida cotidiana de cualquier país latinoamericano? Sin pretendernegar las modalidades nacionales de un gran país como la Argentina, el Brasil o México, habria que ser ciego para no ver que este mismo país se inscribe en la evolución y los avatares que han alcanzado a todo un continente y para no sentir, al mismo tiempo, que queda tironeado entre sus diferentes componentes regionales (para no hablar de otros componentes, étnicos, lingüísticos, sociales, etc.).

El exilio tiene, a veces, algo de relativo y paradójico. Al lado de todos los exiliados del Nuevo Mundo que, como Cortázar, se sienten profundamente latinoamericanos, otros escritores latinoamericanos - peruanos(García Calderón) o guatemaltecos(Gómez Carrillo), chilenos (Huidobro), cubanos (Manet) o argentinos (Bianciotti) - se sintieron atraídos,

\footnotetext{
${ }^{18}$ El olor de la guayaba (Barcelona: Bruguera, 1982) 73-74.
} 
llamados por París donde terminaron por instalarse, buscar la inspiración y crear, y quisieron, en un momento de su vida, ser tan franceses como latinoamericanos, si no es más. Y se sabe que a Borges - pero no fue probablemente el único, Victoria Ocampo, Mujica Láinez, otros más hubieran podido hacerle compañía- le gustaba proclamarse, con un agudo sentido de la "boutade" y de la provocación, "un europeo exiliado en la Argentina". 19

Vargas Llosa nota que el impacto del exilio -o del no-exilio - en la literatura es ante todo una cuestion personal. En su caso, el exilio - cultural - se revela propicio:

Escribo mejor en el exilio —nos dice. 'Mejor', en este caso, es algo que debe entenderse en términos psicológicos, no estéticos; quiere decir con 'más tranquilidad' o 'más convicción' ${ }^{20}$

Algunos, como El Inca Garcilaso, Bello, Sarmiento, Martí, César Vallejo, Cortázar, han escrito en el exilio una obra muy próxima a la realidad de sus países respectivos, lo que vendría a demostrar que "el exilio no perjudica la capacidad creadora de un escritor [...] y no determina un desgaste, un deterioro, en la visión de su realidad que transmiten sus libros," si no se encontrase precisamente, a la inversa, otros escritores que "al alejarse de su país se frustraron como creadores o escribieron libros que deformaban el mundo que pretendieron describir." A todos estos ejemplos podríamos, llevando las cosas hasta el absurdo, oponer los de todos los escritores que, "sin haber puesto nunca los pies en el extranjero, escribieron mediocre o inexactamente sobre su país" o "escribieron obras que no reflejan la realidad de su país." Así, José María Eguren ha inventado un mundo poblado de hadas y de enigmas nórdicos, mientras que Julián del Casal escribió sobre todo sobre Francia y Japón.

No se exiliaron corporalmente - nota Vargas-pero su literatura puede llamarse exiliada, con la misma justicia con que puede llamarse literatura arraigada la de los exiliados Garcilaso y Vallejo (59).

Sarduy, por su lado, expondrá el caso de Lezama Lima quien, "[no habiendo dejado] nunca ni Cuba, ni su provincia, ni su barrio, ni su casa, ni su habitación", puede legítimamente considerarse como un "exiliado del interior". Eso no impide que "[se encuentren en sus obras] más referencias a los vasos órficos, a los mitos griegos, a las metopas del Partenón, al arte pitagórico, a Nijinski, a Diaghilev que a Cuba."21

Lo único que queda probado - arguye Vargas - es que no se puede probar nada en este dominio y que, por lo tanto, en términos literarios, el exilio no es un problema en sí mismo. [...] La evasión o el arraigo de una obra, como su perfección o imperfección, no tienen nada que ver con el domicilio de su autor. ${ }^{22}$

${ }^{19}$ Le Monde (28 de enero de 1983).

20 "Literatura y exilio", Boletin de la Universidad de Chile, 83-84 (mayo-junio de 1968) 58.

21 Kohut, 268-269.

22 "Literatura y exilio", Boletín de la Universidad de Chile, 83-84 (mayo-junio de 1968) 60. 
Esta declaración es importante porque va mucho más allá de una simple cuestión de fidelidad del reflejo literario con respecto a la realidad del país del autor. De hecho plantea el problema de la "legitimidad" del exilio "cultural". En efecto, si se le reconoce de buena gana al escritor perseguido por la dictadura el derecho a exiliarse (un "derecho" que es a veces una obligación absoluta), algunos no reconocen este mismo derecho al que se ha "autoexiliado" para encontrar en el extranjero unas condiciones más favorables a la eclosión de su obra. Precisamente, Vargas Llosa se ha visto expuesto, tal vez más que cualquier otro, a esos ataques no desprovistos de sectarismo, cuando no se trata de simple envidia literaria

Me llama la atención - escribe- esta preocupación por el domicilio geográfico del escritor. Sobre todo porque parece que la pregunta implica una acusación. Como si esto fuera una traición a su tierra y a su país. [...] En América Latina todo conspira para disuadir al escritor de su vocación. Por eso es que los escritores no salen por fugar de sus paises, sino para no fugar de su vocación. ${ }^{23}$

En el fondo, ¿no resulta esta cuestión del exilio algo bizantina? Sin duda. Por un lado, porque, como lo demostró Vargas Llosa, la expatriación no tiene muchas incidencias sobre el contenido y sobre la calidad de la creación. Por otro lado, porque, como lo ha afirmado James Joyce, como lo han repetido después de él Sarduy y muchos otros, la condición fundamental de la literatura, la condición auténtica de cualquier escritor, es en sí misma una forma de exilio, de ruptura o de "autoproscripción".

Nadie podrá negar - dijo la novelista vietnamita Linda Lê- que, por definición, un escritor se encuentra en el exilio. ${ }^{24}$

Y el escritor marroquí Abdellatif Laâbi pronunció estas palabras exactas y sentidas :

Crear presupone una ruptura, un alejamiento. Porque hay que decir que la creación es una forma de anarquía. La vida, las relaciones sociales y humanas tales como son, funcionan y se perpetúan en una lógica de la reproducción. El equilibrio, el orden llevan este precio. En cambio, la creación es una subversión que no puede menos que atropellar lo admitido, lo establecido, lo adquirido. No existe la creación más que en la insubordinación contra el orden reinante y a todos los niveles: sensible, racional, sociológico, político. La pesadilla de la creación, es el consenso. [...] La postura filosófica del creador es la de la ruptura, de la distancia tomada con todos los vínculos, las costumbres, los lugares comunes de las ideas y de los comportamientos. No puede tomarse más que por un acto de autoproscripción. [...] De modo que no son únicamente las tiranías las que imponen el exilio al creador. Esta forma de exilio es, desde luego, cruel. Constituye una violación incalificable de los derechos del hombre y de la libertad del creador. Pero no debe ocultarnos una realidad más compleja. Porque, en cuanto la crisálida de la creación se libera en nosotros, estamos ya en los umbrales del exilio. El exilio está en nosotros, antes

23 "Los escritores huyen de sus países para no fugar de la realidad", La Nación (Santiago de Chile, 21 de agosto de 1969), citado por Horacio Sal as, "Julio Cortázar: la ubicuidad del exiliado", Cuadernos Hispanoamericanos, 364-366 (octubre-diciembre 1980) 94.

24 "Paroles d'exil", Hommes et migrations: Lettres d'exil, 1142-1143 (avril-mai 1991) 20. 
de imponérsenos. Se revela tan pronto como empieza nuestra migración y se despliega nuestra búsqueda. ${ }^{25}$

Dicho de otro modo, el escritor no queda nunca integrado en su propio país y lleva entre los suyos una existencia de proscrito. Desde este momento, el exilio-político, económico, cultural o exterior, interior, lingüístico, etc.- no hace más que añadir una dimensión o un avatar más a lo que es la condición natural y exclusiva del escritor y del creador.

25 "Exil et création", Hommes et migrations: Lettres d'exil, 1142-1143 (avril-mai 1991) 51 [Las traducciones son nuestras]. 